\title{
BEHAVIOR OF DIVERS AND RECOMMENDATIONS OF OTOLARYNGOLOGISTS CONCERNING DIVING: PILOT STUDY
}

\author{
Liubov Kornilenko ${ }^{1}$, Jelena Stanislavoviene $\dot{1}^{1}$, Irina Arechvo ${ }^{2}$ \\ ${ }^{1}$ Faculty of Medicine, Vilnius University, ${ }^{2}$ Department of Ear, Nose and Throat Diseases, \\ Republican Vilnius University Hospital, Lithuania
}

Keywords: behavior of divers, diving contraindications, ear barotrauma.

\begin{abstract}
Summary
The aim of the study is to estimate the possible risky behavior of Lithuanian divers and its relation to ear damage as well as identify the opinions of Lithuanian otolaryngologists concerning contraindications and recommendations in the diving field.

Material and methods. The authors compiled two separate questionnaires for Lithuanian divers and otolaryngologists; in total, 84 questionnaires were completed. Statistical tests were used to detect the difference among answers of respondents who have distinct sociodemographic characteristics or different diving/consulting experience.

Results. It was revealed that $47.5 \%$ of divers experienced difficulties while equalizing the air pressure. More than half of the divers $(57.9 \%)$ ignored this embarrassment and continued diving. Ear pain was felt by $37.5 \%$ of the respondents during their diving session. Half of the divers consulted a doctor because of the pain, others did not pay attention and proceeded the diving. The third of the interviewed divers were diving though they had rhinitis. Most of them were diving without any medications. Only $13 \%$ of those who experienced dizziness consulted a doctor. Absolute contraindications to dive are a tympanic membrane perforation (90.9\%), myringotomy tube inserted into a tympanic membrane (79.5\%), and Eustachian tube dysfunction (61.4\%); these disorders are most often reported by the interviewed otolaryngologists. In this survey, $61.3 \%$ of the otolaryngologists declared they would allow diving if there were no symptoms of vertigo in the past 3-6 months. The opinion of otolaryngologists on diving in the case of acute rhinitis, as well as on the returning to diving
\end{abstract}

after the stapedoplasty, is different; $15 \%$ of the interviewed doctors would recommend stopping diving for a definite period. Despite the recommendations of doctors, $17.9 \%$ of divers continued to dive.

Conclusions. This study shows that the behavior of divers regarding the hearing health is often quite risky. Lithuanian otolaryngologists are lacking consensus of opinion on contraindications for diving.

\section{Introduction}

Diving is one of the activities that are the fastest growing in popularity. There are more than 10 million certified divers worldwide [1], but the exact number of amateur divers in Lithuania is unknown (the country has more than 20 diving clubs) [2]. Due to significant air pressure changes, the main health problems of divers are associated with ears and sinuses [1]. However, the residency of Lithuanian otolaryngologists does not involve all aspects of diving medicine. Because of the lack of doctor's experience, difficulties can occur while giving advice to divers. It is generally accepted that common ear and nose diseases, e.g. chronic otitis media with perforation, chronic rhinosinusitis and nasal polyposis are contraindications for diving. However, modern treatment methods may increase the expectation for a full recovery and even to restore the ability to dive in many cases. Additionally, there is still no consensus of opinion regarding how long the underwater activity should be prohibited after the usual otolaryngological procedures. The doctors should know about the strong desire of divers to practice diving despite chronic conditions. Previous studies have shown that divers continue to dive despite suffering from contraindications $[3,4]$.

The aim of this paper is to reveal the presence or absence of risky behavior of Lithuanian divers and opinions of otolaryngologists about contraindications and recommendations concerning the diving activity. The researchers of this study believe that the results of it will help the communities of divers and otolaryngologists to understand each other better. 


\section{Materials and methods}

This study has been carried out from July to October in 2015. Two separate questionnaires were created and sent to Lithuanian diving clubs as well as to otolaryngologists via e-mail. The questionnaire for divers included questions concerning demographic data (questions), diving history (), symptoms of ear disorders (), risk factors for the development of ear diseases and diving habits that might affect the occurrence of otological complications (). Knowledge of the divers about their handling different underwater situations () was evaluated as well as frequency of their consultations with medical specialists () and compliance with the recommendations of doctors ().

In the questionnaire, otolaryngologists were asked to provide their sociodemographic data (), information concerning their work experience (), recommendations for divers, contraindications to diving () and their knowledge regarding the treatment of diving-related diseases ().

All eighty-four submitted questionnaires were completed and used in the analysis; the number of respondents is 40 divers and 44 otolaryngologists. The data were analyzed using IBM SPSS Statistics software, version 21.0. ANOVA was employed to compare the means of continuous variables. Chi-square and Fisher's exact test were used to obtain significant differences in proportions of categorical variables. In this paper, the exact test results are presented only using the cases in which statistically significant differences between the groups can be observed $(p<0.05)$.

\section{Results}

This study includes 44 questionnaires completed by otolaryngologists whose average work experience is 20.01 years $(\mathrm{SD}=12.71)$. The most of them ( 24 respondents) have worked both in outpatient departments and hospitals, the others (17 interviewees) have worked entirely in outpatients departments, and only 3 questioned otolaryngologists mentioned a hospital as their sole workplace. Only $34.1 \%$

Table 1. Characteristics of the interviewed ear, nose and throat (ENT) specialists (otolaryngologists) concerning the workplace and the number of divers they had consulted per year $(n=44)$.

\begin{tabular}{|l|c|c|}
\hline Characteristic & $\begin{array}{c}\text { Absolute } \\
\text { numbers }\end{array}$ & $\%$ \\
\hline Workplace & 17 & 38.6 \\
Outpatient department & 3 & 6.8 \\
Hospital & 24 & 54.5 \\
Outpatient department and hospital & & \\
Consulted divers per year & 29 & 65.9 \\
None & 15 & 34.1 \\
From 1 to 10 & & \\
\hline
\end{tabular}

of the interviewed otolaryngologists reported that they had consulted divers in the past 12 months. The largest number of consulted divers per specialist within a year is 10 people (Table 1).

In the study, 40 questionnaires which had been completed by the divers were used as well. The major part of these respondents includes men who have approximately 6 years of diving experience (Table 2). Another characteristic of the interviewed divers is that sixty percent of them have a higher education. Most respondents (95\%) have at least one diving certificate.

Study of otolaryngologists: contraindications for diving and special ear conditions while diving. The conditions noted by otolaryngologists as the absolute contraindications for diving are presented in the Figure 1. The major part of the ENT specialists noted that open tympanic membrane perforation and tube myringotomy are total contraindications to diving. Besides, about half of interviewed specialists think that the records of Eustachian tube dysfunction and open mastoidectomy in patient's medical history are contraindications for diving and only several doctors would prohibit the diving if a patient had other ear health conditions.. The choice of a particular questionnaire's answer overall does not depend on the doctor's job experience, a number of consulted divers per year, respondent's workplace.

In regards to whether patients can continue diving after a surgery (stapedoplasty), 38.6\% of the interviewed otolaryngologists (IOs) proposed the first consultation three months after the surgery, $34.1 \%$ suggested seeing the doctor after one year, and $20.5 \%$ said that diving is contraindicated after the stapedoplasty. The answer choice is related to the duration of work experience. The average work experience of respondents who recommended diving one year after the stapedoplasty is 28.07 years $(\mathrm{SD}=12.2)$ vs. 14.82 years $(\mathrm{SD}=10.66)$ of work experience of those doctors who recommended diving 3 months after the surgery $(F=5.05$, $\mathrm{p}<0.05)$.

The research reveals the opinion of otolaryngologists concerning the about diving when atrophic eardrums can

Table 2. Characteristics of the interviewed divers concerning the age, sex, diving depth and diving experience $(n=40)$.

\begin{tabular}{|l|c|}
\hline Characteristic & $\mathbf{n}=\mathbf{4 0}$ \\
\hline Average age & 35.8 years $(\mathrm{SD}=11.142)$ \\
\hline Sex & $\mathrm{n}=30(75 \%)$ \\
Men & $\mathrm{n}=10(25 \%)$ \\
\hline Women & 22.23 meters $(\mathrm{SD}=8.122)$ \\
\hline Average diving depth & 6.5 years $(\mathrm{SD}=3.83)$ \\
\hline Average diving experience &
\end{tabular}




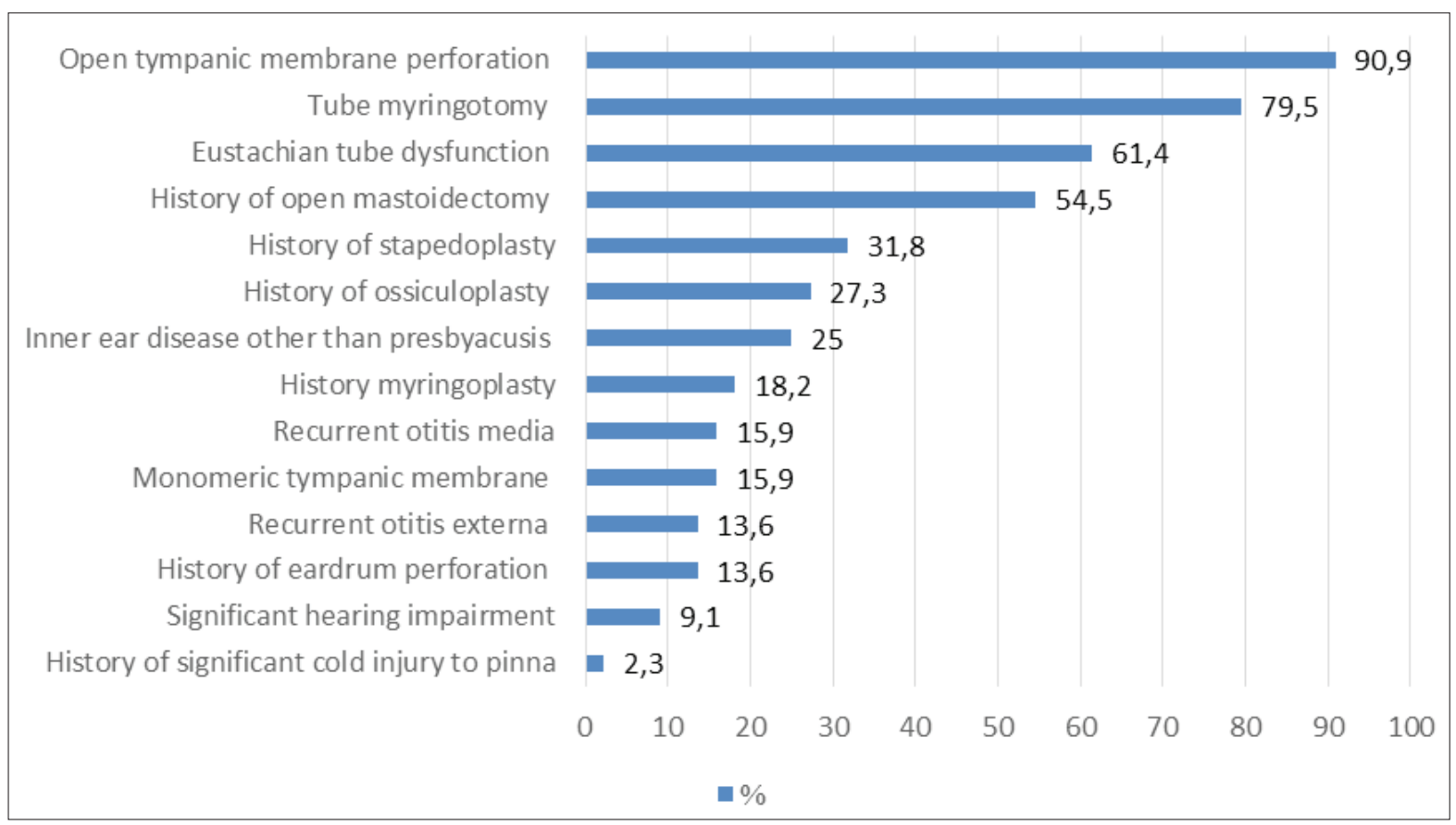

Figure 1. Absolute contraindications for diving noted by the interviewed otolaryngologists.

be seen otoscopically: there are $31.8 \%$ interviewed specialists who were convinced that diving causes ear traumas, so their advice for patients is to stop diving; overall, $61.4 \%$ of the interviewed doctors would allow diving under the supervision of an otolaryngologist and a diving instructor. A few interviewees ( $6.8 \%$ of otolaryngologists) responded that they would let a patient to dive, but before it they would explain the risk of such activity.

Moreover, otolaryngologists were asked about specific ear conditions caused by the changes in pressure, i.e. the differences between inner ear barotrauma (IEB) and inner ear decompression sickness (IEDS). There are $43.2 \%$ respondents who claim that IEB and IEDS are two different pathologies, $95.7 \%$ of interviewers say that the symptoms of these pathologies are similar, and $78.6 \%$ of medical specialists state that the treatment of these pathologies is different. An inappropriate tactics for overcoming IEB (treatment in pressure chamber) has been chosen by $18.2 \%$ of doctors. For IEDS management, $47.7 \%$ of respondents offer necessary treatment using a hyperbaric oxygen chamber. The otolaryngologist's choice of hyperbaric oxygen therapy for treatment of IEDS depends on specialist's duration of work experience $\left(\chi^{2}=4.02, \mathrm{df}=1, p<0.05\right)$; the shorter it is, the more often doctors propose this therapy. In the group of IOs having from 1 to 15 years of work experience, $68.4 \%$ choose treatment using the chamber; the same therapy is chosen by
$12.5 \%$ of doctors having $16-30$ years of work experience and by $12.5 \%$ of those having from 31 to 45 years of work experience.

Study of divers: difficulties equalizing the pressure, ear pain, and diving despite doctor's recommendations. Less than a half of the interviewed divers (IDs), i.e. $47.5 \%$ of them, reported that they had difficulties equalizing the pressure under water, especially when they "caught a cold" or had an "ear infection". Divers who had experienced this difficulty behaved as follows: $15 \%$ (6) of the respondents immediately interrupted the diving, 10\% (4) saw an ENT specialist, and $27.5 \%$ (11) did not pay attention and continued the diving. The latter group includes only the men.

Regarding the ear pain, $37.5 \%$ of divers experienced it while they were diving. Only 8 respondents (20\%) stopped diving and visited a doctor after the occurrence of this symptom, whereas $10 \%$ of divers were searching for information on the Internet how to solve this problem. Despite the pain, $15 \%$ of the interviewees continued the diving without paying attention to the symptom. In the case of an acute ear pain or a feeling of fullness in the ear, $12.5 \%$ of the IDs did not know how to behave. Additionally, $42.5 \%$ of the respondents reported that they would not recognize the symptoms of a ruptured eardrum under the water.

One part of respondents $(15 \%)$ were recommended by the doctors to stop diving for a period of time. However, $17.9 \%$ 
of divers continued to dive despite the recommendations of the doctors.

Vertigo and acute rhinitis. Contradictions between otolaryngologists and divers. Regarding vertigo, $37.5 \%$ of divers experienced it under the water during the diving and $12.5 \%$ of the IDs felt it when they were on the surface of water. Only $5 \%$ of the interviewees complained of this symptom to the ENT specialists. In the case of experiencing dizziness while being under the water, $63.6 \%$ of the interviewed otolaryngologists recommend rising towards the surface of water as slowly as possible, $43.3 \%$ of the ENT doctors advise their patients never return to diving after experiencing vertigo under the water, and $9.2 \%$ of medical specialists suggest exploring the cause of dizziness before the next consultation. If there were no unexplained symptoms of vertigo in the past 3-6 months, $61.3 \%$ of the interviewed specialists would allow the divers to continue their favorite activity. In the case of Meniere's disease or other recurrent peripheral vestibulopathy, $52.3 \%$ of the interviewed otolaryngologists suggest discontinuing diving activity and $40.5 \%$ of ENT doctors recommend to continue the diving under the supervision of a doctor and a diving instructor.

Most of the otolaryngologists (65.9\%) would recommend stopping diving in a period of acute rhinitis while $31.8 \%$ of respondents would allow diving if their patient used antihistamines, decongestants or topical corticosteroids. Furthermore, 12 interviewed divers (30\%) periodically dive with a runny nose and $20 \%$ of them have been doing it without any medications. This behavior is related to the education level of respondents $\left(\chi^{2}=5.030, \mathrm{df}=1, p<0.05\right)$ : more divers whose education is lower periodically have been diving with a runny nose without taking any medication.

\section{Discussion}

SCUBA diving is a widely prevalent activity worldwide; however, the pre-selection system for assessing the health of divers is not perfect. To get a diving certificate, a person should fill out a medical questionnaire [5]. However, according to this study results, there is a possibility that a person would not provide all the information about some important medical conditions because of his strong motivation to dive. It is suggested that objective methods should be used more often, even in the cases of amateur divers. There is a list of relative and absolute contraindications, but how to consult the divers exactly and what advice should be given in each particular case does not seem completely clear [6]. Recommendations generally resemble to the personal advices and opinions of the distinct doctors are often different [7]. Meanwhile, the Divers Alert Network (DAN) emphasizes that the diver must always consult his or her doctor in order to decide whether or not he/she can dive [8]. The authors of this article believe that awareness of the diver's motivation depends on the fact whether the patient will consult the doctor in time or dive without medical supervision despite the contraindications. The minimal effect of forbiddance has been previously mentioned [9].

The present study has revealed that some divers do not recognize potentially dangerous situations happening under the water and do not know how to behave in them, for example, in the case of acute ear pain (possible risk of the eardrum perforation). This finding helps to confirm the hypothesis about the lack of awareness of divers in this situation. According to the literature, it is recommended to stop at the present depth under the water and perform an equalization maneuver; if the symptoms persist, discontinue diving and try to rise to the surface of the water using the decompression station. It is known that correct decisions should be made quickly under the water. It is important not to blow too hard, which is usually done by divers when they panic while trying to equalize the pressure [10]. More attention should be given to this topic in training or during the consultations with an otolaryngologist.

Only half of the IDs consulted the doctors in the event of possible ear injuries. There is a possibility that the symptoms signalizing ear injuries were disturbing the respondents only temporarily or were not very intense. Half of the IDs experienced difficulties equalizing pressure between the middle ear and nasopharynx and felt the ear pain. Difficulties while equalizing the pressure may be associated with the Eustachian tube dysfunction (ETD) which is the risk factor of middle ear barotrauma [11]. The third of the IDs did not pay attention and continued potentially risky activities. The same situation was happening in the case of dizziness; only minority of the IDs consulted an otolaryngologist. Only a number of men chose the answer: "to ignore the symptoms and continue to dive". Certainly, behavior is not determined only by gender and attitude towards health depends on a person's character [12], but such results may confirm that overall, men tend to take risks more often and care less about their health than women [13]. It should be highlighted that $17.9 \%$ of divers claimed they would dive despite the recommendations of their doctors not to act in such a way.

One third of the IDs are smokers. The habit of smoking has a relation with education; the higher the education is, the less often (or more rarely) the questioned divers smoke. Smoking is a risk factor for the development of ETD [3]. The survey reveals that the third of the divers continue to dive despite having rhinitis and some of them were diving without any medication, more often the lower educated individuals. The named facts show that behavior of these divers is risky 
and they tend to act dangerously despite the information provided during courses. Recommendations from the IOs differ regarding the diving in the cases of acute rhinitis. In general, the top recommendation is to limit diving during the periods of acute rhinitis. As regards the acute rhinitis, in the medical literature there have been mentioned that the use of topical or systemic decongestants can help (if an individual is continuing to dive, it is better to use these decongestants than to dive without them) [14].

Most commonly recommended absolute contraindications to dive by otolaryngologists are an open tympanic membrane perforation, tube myringotomy, and ETD. According to the literature, the eardrum perforation is attributed to high-risk conditions and to absolute contraindications for diving because of caloric vestibular irritation and the chance of getting an infection $[15,16]$. The authors of medical writings recommend waiting for approximately 2 months after the eardrum perforation will have been healed, then the otolaryngologist should ensure that it was healed well enough and there are no symptoms of ETD [17]. Today, there are special ear protectors for divers that allow the divers to keep their ears dry after the occurrence of eardrum perforation [18].

The medical literature suggests that acute ETD, only in the cases when it is absolutely impossible to carry out the equalization maneuver, is an absolute contraindication to diving [16].

Half of the IOs stated that the patients should never return to diving after the radical ear surgery or having a record of open mastoidectomy in their past medical history. Some authors claim that a patient should not dive after the radical surgery because the flow of cold water inside the cavity can provoke vertigo [19]. Other authors emphasize that effects on the vestibular system may be different and they depend on the size of operations and the access. To determine whether a patient is allowed to dive, a provocative test (posturography with cold water which is poured into the affected ear while changing the patient's body position and monitoring nystagmus at the same time) must be carried out $[15,16]$. In recent years, an increasing number of surgeons have been choosing to perform a mastoidectomy with cavity obliteration because patients can return to their normal water activities after a surgery and drawbacks of open techniques can be avoided.

The current attitude of IOs towards diving after the stapedoplasty can be defined according to the following information: one third of respondents claim that they would forbid the diving after this surgery. The Professional Association of Diving Instructors (PADI) attributes a record of stapedoplasty in patient's medical history to the possible conditions of severe risk. It is known that after the stapes surgery, there remains a danger of prosthesis dislocation into the vestibule of the patient [16]. On the other hand, there are also contradicting opinions of various researchers provided in the medical literature $[6,20]$. Some authors recommend assessing the patient's condition with the help of impedancemetry before his/her returning to diving; if there is no sign of a disturbance, the existing risk should be explained and then the patient should be allowed to dive $[19,21]$. Some IO propose to hold the consultation with the patient one year after the stapedoplasty and others (almost the same number of respondents) suggest to arrange the consultation three months after the surgery. The authors of this article did not separate the otosurgeons and otoneurologists into different groups of specialists; their opinions would probably be the most important. According to the conclusions drawn by House and Toh [22], the risk of inner ear barotrauma after stapes surgery has not been increased in SCUBA divers; they reported that the activity can be relatively safe after the stapedectomy accompanied by the adequate Eustachian tube function.

Myringoplasty is one of the most common otologic procedures; therefore, questions concerning diving after this type of surgery are important and practical. One fifth of the IOs claim that the record of myringoplasty in patient's medical history is an absolute contraindication to diving. An eardrum becomes less stable after the surgery than before; therefore, the risk of perforation remains [15], especially when fascia of the temporal muscle or tragus perichondrium is used. An otolaryngologist should evaluate aeration of the middle ear and stability of the reconstructed tympanic membrane after the each ear surgery. Cartilage tympanoplasty can be an alternative for divers as it provides more stability for the eardrum by becoming more resistant in a pressure-changing environment.

More than half of the IOs would let a patient continue diving under a supervision of an otolaryngologist and a diving instructor. In the medical literature, it has been mentioned that patients who previously had the atrophic eardrum without perforation that remained stable during the equalization maneuver could be allowed to dive. However, the patient should be given explanation about the risk of perforation [15]. Surgery might be proposed (before ultimately forbidding the diving) if increased pressure causes eardrum instability $[6,15]$. Diving in a swimming pool under the supervision of a diving instructor could be proposed to determine if vertigo occurs under the water and the eardrum surgery is needed [19].

Opinions of the IOs are different on the compatibility of Meniere's disease or other known peripheral vestibulopathy with diving activity. One group of specialists claim that such diseases are absolute contraindications to dive; another 
group would allow diving along with otolaryngologist and diving instructor consultations. DAN proposes that only often recurring episodes should be an absolute contraindication to dive [23]. If there are no repeated episodes, the authors recommend the provocation tests and trying to dive in a swimming pool with a diving instructor [19].

In the cases of underwater vertigo, more than half of the IOs suggest moving slowly to the surface of the water and a little less of them would prohibit diving. It is known that underwater vertigo may be a life-threatening because of an increased risk of drowning. Therefore, if it happens often, some authors recommend stop to dive [15]. Divers who experienced alternobaric vertigo (a common finding in divers [24]) had not been consulted about dangerous situations, so the risk is considered being low. Doctors should differentiate the causes of vertigo before allowing their patients to dive. More sophisticated vestibular tests (videonystagmography) might be needed [19,24]. The research revealed on this paper has showed that majority of the respondents would allow diving after a 3-6 month asymptomatic period (more than half of them would choose a 6-month period). According to the literature, absolute contraindications to dive include an acute vestibular impairment after vertigo up to 6 months or signs of nystagmus noticed during a provocation test [15]. The results of this study has showed that there is no consensus among otolaryngologists; therefore, further prospective studies are needed.

The study carried out by the authors of this article shows that the interviewed otolaryngologists rarely consulted divers. This situation has probably emerged because the majority of otologic injuries were minor and divers recovered spontaneously or with the help of online specialists or general practitioners. Another possible explanation is that the interviewed divers were consulted by foreign medical specialists, as the most popular places to dive are generally outside of Lithuania. The study shows a lack of specific knowledge of Lithuanian otolaryngologists concerning the diving. This lack of knowledge is especially noticeable when distinguishing the differences between IEB and IEDS. The authors of this article believe that these two different pathologies should be diagnosed in a timely manner and a proper treatment should be started as soon as possible. Similarities in the symptoms of these pathologies do exist [1], but they can be differentiated considering a thoroughly collected medical history [25]. Symptoms of IEDS are more associated with a prolonged, deep, repetitive diving and breathing a helium-oxygen gas mixture. This medical condition may cause hearing loss, tinnitus, vertigo, nausea and vomiting. IEB can manifest itself as a perilymphatic fistula, intralabyrinthine membrane tear or inner ear hemorrhage. It is difficult to separate IEB from IEDS - it requires a diving risk assessment, thorough examination of patient's medical history, clinical evaluation, pure tone audiometry, fistula test, and electronystagmography [26]. Revision surgery of the middle ear is indicated only in the cases when the patient's condition is severe or if vestibular and auditory symptoms show no improvement within 10 days after the event [26]. Hyperbaric treatment is not needed for IEB healing; the more so, it can cause worsening of the condition [27]. Treatment for IEDS demands recovery of fluid balance, the supply of oxygen through a mask and immediate transportation of the patient to a place where a hyperbaric oxygen therapy chamber is located $[1,28]$.

One of the limitations of the study was that the response rate of otolaryngologists and divers was suboptimal and the authors need further researches to provide more scientifically based conclusions.

\section{Conclusions}

Our study has showed that the habits and behavior of some divers are quite risky. Not all divers know about the ear injuries occurring under the water and how to address potentially life-threatening situations. Attention should be paid to these aspects of diving in diving courses and all possible educational facilities should be used. The interviewed doctors understand the motivation of divers to be involved in their favorite activity, besides, the IOs a wish to satisfy their patients there are no absolute restrictions on the part of doctors. However, Lithuanian otolaryngologists are lacking exact consensus on contraindications for diving; ear injuries should be a more discussed topic to seek for a common solution. There is also a need of knowledge about specific otologic conditions related to diving.

\section{References}

1. Klingmann C, Praetorius M, Baumann I, Plinkert P. Barotrauma and decompression illness of the inner ear: 46 cases during treatment and follow-up. Otol Neurotol 2007;28:447-454. https://doi.org/10.1097/MAO.0b013e318030d356

2. Kornilenko L, Kevanisvili Z, Tusisvili M, Balseris S, Arechvo I. Ear disorders in SCUBA divers. Otorhinolaryngology News 2015/2016;2:14-16.

3. Taylor DM, O'Toole KS, Ryan CM. Experienced, recreational scuba divers in Australia continue to dive despite medical contraindications. Wilderness Environ Med 2002;13:187-193. https://doi.org/10.1580/1080-6032(2002)013[0187:ERSDIA ]2.0.CO;2

4. Beckett A, Kordick MF. Risk factors for dive injury: a survey study. Res Sports 2007;15(3):201-211.

https://doi.org/10.1080/15438620701526779 
5. PADI medical statement. Participant record. 2007. Available from: https://www.padi.com/documents/padi-courses/2.1.5\%20 rstc\%20medstate\%20v201.pdf.

6. Sim RJ, Youngs RP. Otolaryngological requirements for recreational self-contained underwaterbreathing apparatus (SCUBA) diving. J Laryngol Otol 2007;121:306-311.

https://doi.org/10.1017/S0022215106001976

7. Basu S, Georgalas C, Sen P, Bhattacharya AK. Water precautions and ear surgery: evidence and practice in the UK. J Laryngol Otol 2006;121:9-14.

https://doi.org/10.1017/S0022215106003136

8. DAN medical frequently asked questions: ENT surgery. Available from: http:/www.diversalertnetwork.org/medical/faq/.

9. Klingmann C, Praetorius M, Baumann I, Plinkert PK. Otorhinolaryngologic disorders and diving accidents: an analysis of 306 divers. Eur Arch Otorhinolaryngol 2007;264:1243-1251. https://doi.org/10.1007/s00405-007-0353-6

10. Delphia B. Common ear injuries while diving. Divers Alert Diver 1999 Jan/Feb. Available from: http://www.diversalertnetwork.org/medical/articles/Common_Ear_Injuries_While_Diving.

11. Uzun C. Evaluation of predive parameters related to Eustachian tube dysfunction for symptomatic middle ear barotrauma in divers. Otol Neurotol 2005;26:59-64.

https://doi.org/10.1097/00129492-200501000-00010

12. Siwek M, Dudek D, Drozdowicz K, Jaeschke R, Styczen K, Arciszewska A, et al. Temperamental dimensions of the TEMPS-A in male and female subjects engaging in extreme or/and high risk sports. J Affect Disord 2015;170:66-70.

https://doi.org/10.1016/j.jad.2014.08.036

13. Harris CR, Jenkins M. Gender differences in risk assessment: why do women take fewer risks than men? Judgm Decis Mak 2006;1:48-63.

https://doi.org/10.1037/e511092014-212

14. DAN medical frequently asked questions: ear equalizing. Available from: http://www.diversalertnetwork.org/medical/faq/.

15. Klingmann C, Preatorius M, Böhm F, Tetzlaff K, Plinkert $\mathrm{PK}$. Fitness to dive in the otorhinolaryngological field. HNO 2008;56:509-518. https://doi.org/10.1007/s00106-008-1743-9

16. Eichhorn L, Leyk D. Diving medicine in clinical practice. Dtsch Arztebl Int 2015;112:147-158.

https://doi.org/10.3238/arztebl.2015.0147

17. DAN medical frequently asked questions: tympanic membrane rupture. Available from: http://www.diversalertnetwork.org/ medical/faq/.

18. Ear problems in diving. ProEar 2000. Available from: https:// www.proear2000.com/pages/table.html.

19. Klingmann C, Wallner F. Health aspects of diving in ENT medicine. Part II: diving fitness. HNO 2004;52:845-847. https://doi.org/10.1007/s00106-004-1105-1
20. Harill WC, Jenkins HA, Coker NJ. Barotrauma after stapes surgery: a survey of recommended restrictions and clinical experiences. Am J Otol 1996;17:835-846.

21. Hüttenbrink KB. Clinical significance of stapedioplasty biomechanics: swimming, diving, flying after stapes surgery. Adv Otorhinolaryngol 2007;65:146-149.

https://doi.org/10.1159/000098791

22. House JW, Toh EH, Perez A. Diving after stapedectomy: clinical experience and recommendations. Otolaryngol 2001;125:356360.

https://doi.org/10.1067/mhn.2001.118183

23. DAN medical frequently asked questions: Meniere's disease. Available from: http://www.diversalertnetwork.org/medical/ faq/.

24. Klingman C, Knauth M, Praetorius M, Plinkert PK. Alternobaric vertigo - really a hazard? Otol Neurotol 2006 Dec;27(8):11201125 .

https://doi.org/10.1097/01.mao.0000235373.78116.a8

25. Harrill WC. Barotrauma of the middle and inner ear. Baylor College of Medicine 1995. Available from: http://judas.sgul. ac.uk/nelhpc/pcel/cache.php?id=819.

26. The Bobby R. Alford Department of Otorhinolaryngology and Communicative Sciences, 1995.

27. Elliott EJ, Smart DR. The assessment and management of inner ear barotrauma in divers and recommendations for returning to diving. Diving Hyperb Med 2014;44:208-222.

28. Rios Lima MA, Farage L, Lancia Cury MC, Bahamad Júnior F. Update on middle ear barotrauma after hyperbaric oxygen therapy - insights on pathophysiology. Int Arch Otorhinolaryngol 2014;18:204-209.

https://doi.org/10.1055/s-0034-1366974

29. Lynch JH, Bove AA. Diving medicine: a review of current evidence. J Am Board Fam Med 2009;22:399-407. https://doi.org/10.3122/jabfm.2009.04.080099

\section{NARDYTOJŲ ELGESYS IR OTORINOLARINGOLOGŲ REKOMENDACIJOS: BANDOMASIS TYRIMAS}

L. Kornilenko, J. Stanislavovienė, I. Arechvo

Raktažodžiai: nardymas, kontraindikacijos, ausų barotrauma. Santrauka

Tyrimo tikslas buvo išsiaiškinti, ar Lietuvoje gyvenantys nardytojai rizikuoja savo ausų sveikata, ir sužinoti gydytojų otorinolaringologų nuomonę apie nardymo kontraindikacijas bei šių specialistų rekomendacijas dèl tam tikrų su nardymu susijusių sveikatos sutrikimų.

Medžiaga ir metodai. Autorių sukurtos anketos buvo išsiųstos Lietuvoje gyvenantiems nardytojams ir otorinolaringologams užpildyti. Atgal su atsakytais klausimais iš respondentų tyrèjams grị̌zo 84 anketos.

Rezultatai. Iš viso 47,5 \% apklaustų narų jautė sunkumą, bandydami išlyginti slègị po vandeniu. Daugiau nei pusė narų $(57,9 \%)$ 
nekreipe ị ši pojūtį dèmesio ir nardè toliau. Ausies skausmą nardydami jautẻ 37,5 \% apklaustų narų. Dèl šios priežasties puse iš jų kreipèsi ị specialistus, kita dalis nekreipe i i skausmą dẻmesio ir tęsè nardymą. Trečdalis apklaustujų nardè, sirgdami sloga. Didžioji dalis jų užsièmè nardymu, prieš tai neišgèrę jokių vaistų. Tik 13 \% nardytojų, patyrusių galvos svaigimą, kreipèsi ị specialistus. Dažniausiai ototrinolaringologų nurodomos absoliučiosios nardymo kontraindikacijos yra būgnelio perforacija (90,9\%), būgnelyje esantis timpanostominis vamzdelis $(79,5 \%)$ ir ausies trimito disfunkcija (61,4\%). Apskritai 61,3\% apklaustų otorinolaringologų leistų savo pacientui nardyti, kai po galvos svaigimo yra praèjęs 3-6 mèn. besimptominis laikotarpis. Dèl nardymo ūmaus rinito laikotarpiu ir įvykus stapedoplastikai, otorinolaringologų nuomonès išsiskyrè. Iš viso 15 \% šių gydytojų rekomendavo nenardyti tam tikrą laikotarpic. Nepaisant specialistų rekomendacijų, $17,9 \%$ apklaustų narų tęsè nardymą.

Išvados. Tyrimas atskleidè gana rizikingą su ausų sveikatos būkle susijusį nardytojų elgesį. Lietuvos otorinolaringologų nuomonès dèl nardymo kontraindikacijų išsiskyrè - trūksta bendro sutarimo, konsultuojant narus.

Adresas susirašinėti: jelena.stanislavoviene@mf.vu.lt

Gauta 2019-11-15 